\title{
Increasing Teacher Creativity through Strengthening Transformational Leadership, Teamwork, and Work Engagement
}

\author{
Sasli Rais*, Bibin Rubini, Herfina \\ Universitas Pakuan, Bogor, Indonesia
}

\begin{abstract}
Teacher creativity is needed to encourage the improvement of the quality of school graduates, so that in the end it will accelerate the achievement of national education goals in Indonesia. This study aims to find strategies and ways to increase teacher creativity to be used as input and recommendations for related parties, namely teachers, school principals, and the office of the ministry of religion. This is done by testing the strength of the relationship between teacher creativity $(\mathrm{Y})$ and transformational leadership (X1), teamwork (X2, and work engagement (X3). This research uses correlational research methods, and is carried out using quantitative methods and data collection through surveys. then explained by statistical analysis, analyzed by correlational analysis and SITOREM analysis. The population of this study were 163 permanent teachers of madrasah tsanawiayah in Madiun City. The research sample of 116 respondents was determined by the Taro Yamane formula, selected using the proportional random sampling method. The results of quantitative research found that transformational leadership that emphasizes idealized influence, intellectual simulation, inspirational motivation, instructional support, individual consideration, and the influence of ethical values can increase teacher creativity. Teamwork that emphasizes group goals, active participation of members, prioritizing togetherness, communicating with each other, complementing each other, and sharing can improve the quality of teacher services. Work engagement that emphasizes active participation in work, competence, importance of work, development opportunities, level of performance, and interest in organizational goals can improve the quality of teacher services.
\end{abstract}

Keywords: Teacher Creativity, Transformational Leadership, Teamwork, Work Engagement

\section{INTRODUCTION}

The existence of these educators is very important in education, but this is still a problem in the field of education which results in, among others: quality learning has not run optimally and evenly across regions, the efforts made have not been able to improve the quality of learning that fosters higher order thinking skills. thinking skills). The results of the Program for International Student Assessment (PISA) test results were created to test the average academic performance of school children in each country in the areas of Mathematics, Science, and Reading Ability. PISA is organized by the OECD (Organization for Economic CO-operation and Development), where the PISA results from 2009, 2012, 2015 and 2018, have not shown good progress where the 2018 PISA results, Indonesia ranks 72 compared to 78 participating countries (Renstra Kemendikbud 2020 -2024).

Likewise, based on the scores in the implementation of the teacher competency test (UKG) in 2019, where there were 7 provinces that scored achieving the national minimum competency standard (SKM), an average of 55, namely DI Yogyakarta (67.02), Central Java (59.10), DKI Jakarta (62.58), East Java (60.75), Bali (60.12), Bangka Belitung (59.07), and West Java (58.97). While the UKG results are for the pedagogic and professional fields, where the national average is 53.02. The UKG results for pedagogic competencies, the national average is only 48.94 , which is below the SKM where there is only one province whose scores are above the national average and at the same time achieving SKM, namely DI Yogyakarta (56.91) (https:// npd.kemdikbud.go.id).

According to Oktavia (2014: 308) that as an educator, teachers are required to be more creative in the learning process. Creative teachers are very important for a student (student). The importance of teacher creativity in learning, among others: 1) teacher creativity is useful for increasing student interest in subjects. The application of teacher creativity products, for example in the form of instruments that are able to invite students to learn into the real world through visualization, will be able to reduce students' boredom and increase their interest in lessons; 2) teacher creativity is

Corresponding Author e-mail: sasli2014@gmail.com https://orcid.org/xxxxxxxxxxxxxxxxxxxx

How to cite this article: Rais S, Rubini B, Herfina (2022). Increasing Teacher Creativity through Strengthening Transformational Leadership, Teamwork, and Work Engagement. Pegem Journal of Education and Instruction, Vol. 12, No. 1, 2022, 232-241

Source of support: Nil

Conflict of interest: None.

DOI: $10.47750 /$ pegegog.12.01.24

Received: 23.09 .2021

Accepted: 21.12 .2021

Publication: 01.01.2022 
useful in transferring information more fully. The results of innovation in the form of educational aid instruments will provide complete data or information, this can be seen in the active senses of students, both the senses of sight, hearing and smell, so that students seem to encounter situations that are like the original; 3) teacher creativity is useful in stimulating students to think more scientifically in observing social phenomena or natural phenomena which are the object of study in learning; and 4) teacher creativity will stimulate students' creativity. The importance of teacher creativity is also supported by several recent research results related to creativity (state of the art), including: research conducted by Ida Ayu Dewi Wijayanti and Wayan Gede Supartha (2019), where the results of the study indicate a significance level of transformational leadership of $0.000<0.05$ where the beta value of 0.286 means that transformational leadership has a positive and significant effect on employee creativity.

Based on data and facts obtained through a preliminary survey conducted from 07-12 January 2021, using a questionnaire that the creativity of teachers at MTs Mudadiyah, MTs Agriculture, MTs Madiun, and MTs Siti Hajar in Madiun City still needs to be improved. Preliminary survey in the form of statements to 30 respondents from 4 (four) schools. The statement submitted to the teacher's creativity variable consists of 20 questions, with the answers Always, Often, Sometimes, Never, and Never, based on the indicators: 1) Motivation from within, 2) Ideas (ideas) new, 3) new and unique ways of solving problems, 4) openness to finding new ideas from other people who are better, 5) development of existing works, and 6) benefit of the resulting product.

- The facts are generated based on the results of a preliminary survey using a questionnaire, it can be concluded that teachers are still having problems in terms of creativity, where:

- There are $51 \%$ of teachers who have not been able to motivate themselves from within, which can be seen from teachers being motivated to be creative teachers in carrying out teaching and learning activities, teachers believe in their abilities in carrying out teaching and learning activities, and teachers act flexibly in an effort to support the implementation of teaching and learning process activities.

- There are $57 \%$ of teachers who have not been able to develop new ideas (ideas) for the learning process, which can be seen from teachers taking innovative actions in an effort to support the implementation of teaching and learning activities, teachers have ideas (ideas) who are new in carrying out teaching and learning activities, teachers try to find new opportunities (ways) that are better in carrying out the teaching and learning process, and teachers learn new things to support the implementation of teaching and learning activities.

- There are $57 \%$ of teachers who have not been able to create new and unique ways to solve every problem in the learning process, which can be seen from the teacher being responsive to the problems that occur in carrying out the teaching and learning process, the teacher doing challenging activities to support the implementation of the process activities. teaching and learning, and teachers solve problems in the teaching and learning process in new ways.

- There are $58 \%$ of teachers who do not yet have openness to finding new ideas from other people who are better to support the learning process, which can be seen from teachers adapting to changes in the implementation of the teaching and learning process, teachers being open to accepting ideas (ideas). new ideas from other people that are better to support the implementation of the teaching and learning process, teachers adapt to changes in the implementation of the teaching and learning process, and teachers are open to accepting new ideas (ideas) from other people who are better at supporting the implementation teaching and learning process.

- There are $60 \%$ of teachers who have not been able to develop the work that already exists to support the learning process, which can be seen from the teacher being open to new products produced by other people who are better at supporting the implementation of the teaching and learning process, teachers like to develop works that are has been made by themselves to support the implementation of the learning process, and teachers like to develop the work that has been made by others to support the implementation of the teaching and learning process.

- There are $59 \%$ of teachers who have not been able to take advantage of the products produced, which can be seen from the products produced by teachers can be used by themselves to support the implementation of the teaching and learning process, the products produced by teachers are used by schools (organizations) to support the implementation of the learning process teaching, and the products produced by the teacher are used by other people (other teachers) to support the implementation of the teaching and learning process.

Therefore, based on the results of previous studies and the results of this preliminary study, it can be concluded that creativity is still an interesting study for further research because there are many factors that provide opportunities for increasing teacher creativity, as well as problems faced both from leadership factors, work environment, infrastructure, and other factors so that this research is expected to provide a novelty for increasing teacher creativity and can contribute to education management science.

\section{Method}

This research was conducted in Madrasah Tsanawiyah (MTs), namely MTs Al Mujaddadiyyah, MTs Agriculture, MTs Madiun, and MTs Siti Hajar spread over 3 sub-districts in 
Madiun City, East Java Province. With a research time of 6 (six) months starting from May to October 2021. The design and constellation of this study used a correlational research flow which was analyzed using SITOREM analysis. As stated by S. Hardhienata (2017), For the purpose of operations research in education management, we need to add the scientific identification theory mentioned above with statistical model and steps to obtain an optimal solution. identification theory mentioned above with statistical model and steps to get optimal solution).

The analytical model tested in this study can be seen in the following Figure 1:

The population is a generalization area consisting of: objects/subjects that have certain qualities and characteristics determined by the researcher to be studied and then draw conclusions. , and MTs Siti Hajar spread over 3 sub-districts in Madiun City, East Java Province. Madrasah Tsnawiyah (MTs) in Madiun City, totaling 163 teachers. The sample is part of the number and characteristics possessed by the population. The research sample amounted to 116 teachers who were determined using the proportional random sampling technique

Based on the theoretical review and framework mentioned above, the following research hypotheses can be proposed:

- There is a positive relationship between transformational leadership and teacher creativity so that strengthening transformational leadership can increase teacher creativity,

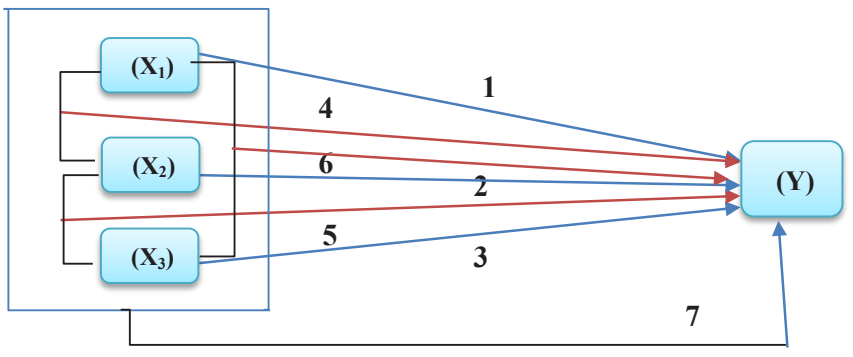

Fig. 1: Research Constellation

X1 : Transformational Leadership Variable (Independent Variable), X2 : Teamwork Variable (Free Variable),

X3 : Work Engagement Variable (Independent Variable), Y : Teacher Creativity Variable (Bound Variable).
- There is a positive relationship between teamwork and teacher creativity so that strengthening teamwork can increase teacher creativity,

- There is a positive relationship between work engagement and teacher creativity so that strengthening work engagement can increase teacher creativity,

- There is a positive relationship between transformational leadership and teamwork together with teacher creativity so that strengthening transformational leadership and teamwork together can increase teacher creativity,

- There is a positive relationship between transformational leadership and work engagement together with teacher creativity so that strengthening transformational leadership and work engagement together can increase teacher creativity,

- There is a positive relationship between teamwork and work engagement together with teacher creativity so that the strengthening of teamwork and work engagement together can increase teacher creativity,

- There is a positive relationship between transformational leadership, teamwork and work engagement together with teacher creativity so that strengthening transformational leadership, teamwork and work engagement together can increase teacher creativity.

\section{Result and Discussion}

Testing the hypothesis of this study using regression and correlation. The first, second and third hypotheses were analyzed by simple regression and correlation. Furthermore, the fourth to seventh hypotheses correlation analysis using multiple regression (multiple regression).

SITOREM analysis is carried out by identifying and analyzing three things (Sunaryo \& Setyaningsih, 2018), namely: 1) Identification of the strength of influence between the independent variable and the dependent variable, 2) Analysis of the value of research results for each indicator of the research variable, and 3) Analysis of the weights each indicator of each research variable is based on the criteria of cost, benefit, urgency and importance. which need to be repaired immediately and which need to be maintained.

Table 1. Summary of Regression Model and Significance Test Results

\begin{tabular}{llll}
\hline No & Correlation & Regresion Model & Result \\
\hline 1 & $\mathrm{Y}$ atas $\mathrm{X}_{1}$ & $\hat{\mathrm{Y}}=76.699+0,409 \mathrm{X}_{1}$ & Sig \\
2 & $\mathrm{Y}$ atas $\mathrm{X}_{2}$ & $\hat{\mathrm{Y}}=81.740+0,407 \mathrm{X}_{2}$ & Sig \\
3 & $\mathrm{Y}$ atas $\mathrm{X}_{3}$ & $\hat{\mathrm{Y}}=78.992+0,429 \mathrm{X}_{3}$ & Sig \\
4 & $\mathrm{Y}$ atas $\mathrm{X}_{1 \text { dan }} \mathrm{X}_{2}$ & $\hat{\mathrm{Y}}=70.264+0,142 \mathrm{X}_{1}+0,326 \mathrm{X}_{2}$ & Sig \\
5 & $\mathrm{Y}$ atas $\mathrm{X}_{1 \text { dan }} \mathrm{X}_{3}$ & $\hat{\mathrm{Y}}=69.744+0,116 \mathrm{X}_{1}+0,362 \mathrm{X}_{3}$ & Sig \\
6 & $\mathrm{Y}$ atas $\mathrm{X}_{2 \text { dan }} \mathrm{X}_{3}$ & $\hat{\mathrm{Y}}=79.630+0,2466 \mathrm{X}_{2}+0,674 \mathrm{X}_{3}$ & Sig \\
7 & $\mathrm{Y}$ atas $\mathrm{X}_{1,} \mathrm{X}_{2 \text { dan }} \mathrm{X}_{3}$ & $\hat{\mathrm{Y}}=69.982+0,121 \mathrm{X}_{2}+0,273 \mathrm{X}_{2}+0,630 \mathrm{X}_{3 .}$ & Sig \\
\hline
\end{tabular}


Increasing Teacher Creativity through Strengthening Transformational Leadership, Teamwork, and Work Engagement

Table 2: Summary of Research Hypothesis Test Results

\begin{tabular}{llll}
\hline No & Hipothesss & Coeficient & Result \\
\hline 1 & Transformational Leadership (X1) with Teacher Creativity (Y) & 0,429 & Positive Relationship \\
2 & Teamwork (X2) with Teacher Creativity (Y) & 0,512 & Positive Relationship \\
3 & Work Engagement (X3) with Teacher Creativity (Y), & 0,532 & Positive Relationship \\
4 & Transformational Leadership (X1) and Teamwork (X2) together with Teacher Creativity (Y) & 0,523 & Positive Relationship \\
5 & Transformational Leadership (X1) and Work Engagement (X3) together with Teacher & 0,539 & Positive Relationship \\
& $\begin{array}{l}\text { Creativity (Y) } \\
6\end{array}$ & $\begin{array}{l}\text { Teamwork (X2) and Work Engagement (X3) together with Teacher Creativity (Y) } \\
7\end{array}$ & $\begin{array}{l}\text { Transformational Leadership (X1), Teamwork (X2) and Work Engagement (X3) together } \\
\text { with Teacher Creativity (Y) }\end{array}$ \\
\end{tabular}

\section{The Relationship between Transformational Leadership and Teacher Creativity}

Based on the hypothesis test in the regression equation, it is known that the probability value (sig.) is 0.000 , meaning less than : 0.05 and 0.01 so it can be concluded that the regression equation $=76.699+0.409 \mathrm{X} 1$ is significant. Thus, the equation $=76,699+0,409 \mathrm{X} 1$ can be used to predict Teacher Creativity (Y) based on the value of Transformational Leadership. (X1). This equation means that every increase of one unit of Transformational Leadership (X1) will increase 0.409 level of Teacher Creativity (Y) with a constant of 76,699.

Likewise, in the Linearity Test, the probability value (sig.) at deviation from linearity is 0.184 , which is greater than ( 0.05 or 0.01$)$, so the deviation from this linear state is not significant, meaning that the regression between the two leadership variables Transformational leadership with teacher creativity is linear. Based on the Correlation Coefficient Test, to see the strength of the relationship between Transformational Leadership (X1) and Teacher Creativity (Y) as indicated by the correlation coefficient value, the $\mathrm{R}$ value (correlation coefficient) of Transformational Leadership and Teacher Creativity (ryl) of 0.429 . The ryl value of $0.429>0$, which means that there is a positive relationship between Transformational Leadership (X1) and Teacher Creativity (Y) where based on Guilford's criteria a value of 0.429 means that the relationship is quite strong, with a probability value (sig.) 0.000 less than ( 0.05 or $0.01)$ states that the correlation is significant.

While the value of the Coefficient of Determination, the value of $\mathrm{r} 2 \mathrm{yl}=0.4292=0.1840$ means that $18.40 \%$ of the diversity in Teacher Creativity (Y) can be explained by diversity in Transformational Leadership (X1) or the contribution of Transformational Leadership (X1) to Teacher Creativity (Y) by $18.40 \%$, while the remaining $71.60 \%$ is a contribution from other factors outside of transformational leadership. Therefore, the value of the correlation coefficient $(\mathrm{R})$ is 0.429 , which means that the variable Transformational Leadership (X1) with Teacher Creativity (Y) have a fairly strong correlation or relationship. The value of the coefficient of determination $(R$
Square) is 0.184 , which indicates that $18.4 \%$ of the variation of the Teacher Creativity variable $(\mathrm{Y})$ is influenced by the Transformational Leadership factor (X1), while the remaining $81.6 \%$ is influenced by other factors.

Transformational leadership is behavior that influences and inspires followers (subordinates, employees) to achieve extraordinary results (exceeding set expectations), in the process of developing their own leadership capacity to achieve organizational goals and vision. Transformational leadership from the head of madrasa tsanawiayah for teachers is an idealized influence, inspirational motivation. intellectual simulation, individual consideration, the influence of ethical/ moral values from the leader being followed, and instructional support.

Based on the results of SITOREM analysis, there is a relationship between transformational leadership and teacher creativity by looking at the weight of the score for each indicator on the transformational leadership variable, namely: idealized influence, the leader acts as a role model or role model (18\%), ranks first with empirical findings on average (4.25); intellectual simulation, a leader who stimulates people to be creative and innovative (18\%), ranks second with an average empirical finding (4.20); inspirational motivation, the leader creates a clear picture of the future state, optimistically (17\%), which ranks third with an average empirical finding (4.17); instructional support, instructional support (16\%), ranks fourth with an average empirical finding (4.71); followed by individual consideration, leaders who develop people by creating a supportive environment (16\%) ranks sixth with an average empirical finding (3.55), and finally the influence of ethical/moral values from leaders followed by followers and groups (14\%), ranks sixth with an average empirical finding (4.27).

\section{The Relationship between Teamwork and Teacher Creativity}

Based on the hypothesis test on the regression equation, it is known that the probability value (sig.) is 0.000 which is less 
than : 0.05 and 0.01 so it can be concluded that the regression equation $=81.740+0.407 \mathrm{X} 1$ is declared significant. Thus, the equation $=81.740+0.407 \mathrm{X} 2$ can be used to predict teacher creativity based on the value of teamwork. This equation means that every increase in one unit of Teamwork (X2) will increase the level of Teacher Creativity by 0.407 (Y) with a constant of 81.740 .

Likewise, based on the Linearity Test, the probability value (sig.) at deviation from linearity is 0.549 more than ( 0.05 or 0.01$)$, then the deviation from the linear state is not significant, meaning that the regression between the two variables (teamwork with teacher creativity) ) is linear.Based on the Correlation Coefficient Test, to see the strength of the relationship between Teamwork (X2) and Teacher Creativity (Y) which is indicated by the correlation coefficient value, the $\mathrm{R}$ value (correlation coefficient) of teamwork with teacher creativity (ry2) is 0.512 . The ry 2 value of $0.512>0$ is interpreted as there is a positive relationship between Teamwork (X2) and Teacher Creativity (Y) where based on Guilford's criteria, a value of 0.512 means that the relationship is quite strong.

The correlation coefficient between teamwork and teacher creativity (ry2) is 0.512 . The ry 2 value of $0.512>0$ is interpreted as a positive relationship between Teamwork (X2) and Teacher Creativity (Y) with a probability value (sig.) 0.000 less than ( 0.05 or 0.01 ) stating that the correlation is significant.

While the value of the Coefficient of Determination, the value of $\mathrm{r} 2 \mathrm{y} 2=0.5122=0.2621$ means that $26.21 \%$ of the diversity in Teacher Creativity (Y) can be explained by the diversity in Teamwork (X2) or the contribution of Teamwork (X2) to Teacher Creativity (Y) of $26.21 \%$, while the remaining $73.79 \%$ is a contribution from other factors outside of teamwork.Therefore, it is known that the correlation coefficient (R) is 0.512 , which means that the Teamwork (X2) variable with Teacher Creativity (Y) has a fairly strong correlation or relationship. The coefficient of determination (R Square) is 0.2621 , which indicates that $26.21 \%$ of the variation of the Teacher Creativity variable $(\mathrm{Y})$ is influenced by Teamwork (X2), while the remaining $7379 \%$ is influenced by other factors.

Based on the results of SITOREM analysis, there is a relationship between teamwork and teacher creativity by looking at the weight of the score for each indicator on the teamwork variable, namely: having the same goal / group goals (19\%), ranking first with empirical findings on average (4.24) ; active participation of members (19\%), ranks second with an average empirical finding (4.09); prioritizing cohesiveness (17\%), which ranks third with an average empirical finding (4.79); interconnected (interacting), communicate dynamically (16\%), ranks fourth with an average empirical finding (3.72); followed by members who complement each other's skills and expertise (16\%), ranks fifth with an average empirical finding (3.18); and finally sharing knowledge (13\%), ranks sixth with an average empirical finding (3.90).

\section{The Relationship between Work Engagement and Teacher Creativity}

Based on the hypothesis test in the regression equation, it is known that the probability value (sig.) is 0.000 , which is less than: 0.05 and 0.01 so it can be concluded that the regression equation $=78.992+0.429 \times 3$ is declared significant. Thus, the equation $=78.992+0.429 \mathrm{X} 3$ can be used to predict teacher creativity based on the value of work engagement. This equation means that each increase of one unit of Work Engagement (X3) will increase 0.429 level of Teacher Creativity (Y) with a constant of 78.992.

Likewise, based on the Linearity Test, the probability value (sig.) on the deviation from linearity is 0.754 more than $(0.05$ or 0.01 ), the deviation from the linear state is not significant, meaning that the regression between the two variables (work engagement with creativity teacher) is Linear. Based on the Correlation Coefficient Test, to see the strength of the relationship between Work Engagement (X3) and Teacher Creativity $(\mathrm{Y})$ which is indicated by the correlation coefficient value, the $\mathrm{R}$ value (correlation coefficient) of work engagement with teacher creativity (ry3) is 0.532 . The ry3 value of $0.532>$ 0 means that there is a positive relationship between Work Engagement (X3) and Teacher Creativity (Y) where based on Guilford's criteria that the ry3 value of 0.532 means that the relationship is quite strong. The correlation coefficient between work engagement and teacher creativity (ry3) is 0.532 The ry3 value of $0.532>0$ is interpreted as a positive relationship between Work Engagement (X3) and Teacher Creativity (Y) with a probability value (sig.) 0.000 less than $(0.05$ or 0.01$)$ stating that the correlation is significant. While the value of the Coefficient of Determination, the value of $\mathrm{r} 2 \mathrm{y} 3=0.5322=$ 0.2830 means that $28.30 \%$ of the diversity in Teacher Creativity (Y) can be explained by the diversity in Work Engagement (X3) or the contribution of Work Engagement (X3) with Teacher Creativity (Y) on Teacher Creativity (Y) by $28.30 \%$, while the remaining $71.70 \%$ is a contribution from other factors outside of work engagement.

Based on the results of SITOREM analysis, there is a relationship between work engagement and teacher creativity by looking at the weight of the scoring of each indicator on the work engagement variable, namely: actively participating in work (19\%), ranks first with empirical findings on average (4.32); have competence for their work (18\%), ranks second with average empirical findings (3.66); the importance of work to individuals (16\%), which ranks third with an average empirical finding (3.98); opportunities for self-development (16\%), ranks fourth with an average empirical finding (3.58); followed by the level of performance that is considered important for self-esteem (15\%), ranks fifth with an average empirical finding (3.92), and lastly is attracted/called by the goals to be achieved by the organization (15\%), ranks sixth with empirical findings average (3.87). 


\section{Relationship between Transformational Leadership and Teamwork together with Teacher Creativity}

Based on the hypothesis test in the regression equation, it is known that the probability value (sig.) is 0.000 , which is less than : 0.05 and 0.01 so it can be concluded that the regression equation $=70.264+0.142 \mathrm{X} 1+0.326 \mathrm{X} 2$. declared significant. Thus, the equation $=70.264+0.142 \mathrm{X} 1+0.326 \mathrm{X} 2$. can be used to predict Teacher Creativity (Y) based on the values of Transformational Leadership (X1) and Teamwork (X2).

Based on the Correlation Coefficient Test, to see the strength of the relationship between Transformational Leadership (X1) and Teamwork (X2) together with Teacher Creativity (Y) which is indicated by the correlation coefficient value, the $\mathrm{R}$ value (correlation coefficient) transformational leadership and teamwork with teacher creativity (ry12) of 0.523 . The ryl2 value of $0.5243>0$ is interpreted as there is a positive relationship between Transformational Leadership (X1) and Teamwork (X2) together with Teacher Creativity (Y) where based on Guilford's criteria, the ry12 value of 0.523 is interpreted as the relationship is quite strong.

While the value of the coefficient of determination, the value of the coefficient of determination ( $\mathrm{R}$ Square), $\mathrm{r} 2 \mathrm{y} 12=0.5232=0.274$ means that $27.40 \%$ of the diversity in Teacher Creativity (Y) can be explained by the diversity in Transformational Leadership (X1) and Teamwork (X2) together. the contribution of Transformational Leadership (X1) and Teamwork (X2) together to Teacher Creativity (Y) is $27.40 \%$, while the remaining $72.60 \%$ is a contribution from other factors outside of transformational leadership and teamwork.

The findings regarding the relationship between transformational leadership and teamwork with teacher creativity in general in this study that there is a significant positive relationship between transformational leadership and teamwork with teacher creativity. The implication is that madrasah tsanawiyah teachers need to strengthen transformational leadership and teamwork together to increase teacher creativity.

\section{Relationship between Transformational Leadership and Work Engagement together with Teacher Creativity}

Based on the hypothesis test on the regression equation, it is known that the probability value (sig.) is 0.000 , which is less than : 0.05 and 0.01 so it can be concluded that the regression equation $=69.744+0.116 \mathrm{X} 1+0.362 \mathrm{X} 3$. declared significant. Thus, the equation $=69.744+0.116 \mathrm{X} 1+0.362 \mathrm{X} 3$. can be used to predict Teacher Creativity (Y) based on the value of Transformational Leadership (X1) and Work Engagement (X3).

Based on the Correlation Coefficient Test, to see the strength of the relationship between Transformational Leadership (X1) and Work Engagement (X3) together with Teacher Creativity (Y) which is indicated by the correlation coefficient value, the $R$ value (correlation coefficient) Transformational Leadership and Work Engagement with Teacher's creativity (ry13) is 0.539 . The ryl3 value of $0.291>0$ which means that there is a positive relationship between Transformational Leadership (X1) and Work Engagement (X3) together with Teacher Creativity (Y) where based on Guilford's criteria, the ry13 value of 0.539 means that the relationship is quite strong.

While the value of the coefficient of determination, the value of the coefficient of determination (R Square), $\mathrm{r} 2 \mathrm{y} 13=0.5392=$ 0.291 means that $29.10 \%$ of the diversity in Teacher Creativity (Y) can be explained by the diversity in Transformational Leadership (X1) and Work Engagement (X3) together Together or the contribution of Transformational Leadership (X1) and Work Engagement (X3) together on Teacher Creativity (Y) is $29.10 \%$, while the remaining $70.80 \%$ is a contribution from other factors outside of transformational leadership and work engagement.

Transformational leadership is behavior that influences and inspires followers (subordinates, employees) to achieve extraordinary results (exceeding set expectations), in the process of developing their own leadership capacity to achieve organizational goals and vision. Transformational leadership from the head of madrasa tsanawiayah for teachers is an idealized influence, inspirational motivation. intellectual simulation, individual consideration, the influence of ethical/moral values from the leader being followed, and instructional support. Work engagement is the identification of an individual's commitment to his work, actively participates in it and considers the level of performance it produces is very important for his self-esteem. With the transformational leadership of the principal and the engagement of the teacher's work, it will be able to stimulate teachers to have self-motivation, new ideas, new and unique ways of solving problems, openness to discovery of ideas. -new ideas from other people who are better, development of existing works, and the benefits of the resulting product.

\section{Relationship between Teamwork and Work Engagement together with Teacher Creativity}

Based on the hypothesis test on the regression equation, it is known that the probability value (sig.) is 0.000 , which is less than : 0.05 and 0.01 so it can be concluded that the regression equation is $=79.630+0.246 \mathrm{X} 2+0.674 \mathrm{X} 3$. declared significant. Thus, the equation is $=79.630+0.246 \mathrm{X} 2+0.674 \mathrm{X} 3$. can be used to predict Teacher Creativity (Y) based on Teamwork (X2) and Work Engagement (X3) scores.

Based on the Correlation Coefficient Test, to see the strength of the relationship between Teamwork (X2) and Work Engagement (X3) together with Teacher Creativity (Y) which is indicated by the correlation coefficient value, the $R$ value (correlation coefficient) teamwork and work engagement with 
teacher creativity (ry23) of 0.535 . The r2y23 value of $0.535>$ 0 which means that there is a positive relationship between Teamwork (X2) and Work Engagement (X3) together with Teacher Creativity (Y) where based on Guilford's criteria, the r2y2 value of 0.535 means that the relationship is quite strong.

While the value of the coefficient of determination, the value of the coefficient of determination (R Square), r2y23 $=0.5352=$ 0.287 means that $28.70 \%$ of the diversity in Teacher Creativity can be explained by the diversity in Teamwork (X2) and Work Engagement (X3) together or contribution. Teamwork (X2) and Work Engagement (X3) together contribute to Teacher Creativity (Y) by $28.70 \%$, while the remaining $71.30 \%$ is a contribution from other factors outside of teamwork and work engagement.

The findings regarding the relationship between teamwork and work engagement with teacher creativity in general, this study shows that there is a significant positive relationship between teamwork and work engagement with teacher creativity. The implication is that madrasah tsanawiyah teachers need to strengthen teamwork and work engagement together in order to increase teacher creativity.

Relationship between Transformational Leadership, Teamwork and Work Engagement together with Teacher Creativity

Based on the hypothesis test in the regression equation, it is known that the probability value (sig.) is 0.000 , which is less than: 0.05 and 0.01 so that it can be concluded that the regression equation is $=69.982+0.121 \mathrm{X} 2+0.273 \mathrm{X} 2+0.630 \mathrm{X} 3$ is declared significant. Thus, the equation $=69,982+0,121 \mathrm{X} 2+0,273 \mathrm{X} 2+0,630 \mathrm{X} 3$ can be used to predict Teacher Creativity (Y) based on the values of Transformational Leadership (X1), Teamwork (X2) and Work Engagement (X3).

Based on the Correlation Coefficient Test, to see the strength of the relationship between Transformational Leadership (X1), Teamwork (X2) and Work Engagement (X3) together with Teacher Creativity (Y) which is indicated by the correlation coefficient value, the $\mathrm{R}$ value (correlation coefficient) leadership transformational, teamwork and work engagement with teacher creativity (ry123) of 0.543 . The r $2 y 123$ value of $0.295>0$ which means that there is a positive relationship between Transformational Leadership (X1), Teamwork (X2) and Work Engagement (X3) together with Teacher Creativity (Y), which is based on Guilford's criteria that the r2y123 value of 0.543 is interpreted as a relationship it is Strong enough.

While the value of the coefficient of determination, the value of the coefficient of determination ( $R$ Square), r2y123 $=0,0.5432=0.295$ which means that $29.50 \%$ of the diversity in Teacher Creativity (Y) can be explained by the diversity in Transformational Leadership (X1), Teamwork (X2) and Work Engagement (X3) together or the contribution of Transformational Leadership (X1), Teamwork (X2) and Work Engagement (X3) together to Teacher Creativity (Y) of $29.50 \%$, while the remaining $70.50 \%$ is contributions from other factors outside of transformational leadership, teamwork and work engagement.

The findings regarding the relationship between transformational leadership, teamwork and work engagement together with teacher creativity in general, this research shows that there is a significant positive relationship between transformational leadership, teamwork and work engagement together with teacher creativity. The implication is that teachers need to strengthen transformational leadership, teamwork and work engagement together in order to increase the creativity of MTs teachers in Madiun City.

\section{Conclusion}

Based on the results of the analysis, discussion of research results and hypotheses that have been tested, it can be concluded as follows: Increasing teacher creativity (the dependent variable) can be done by strengthening transformational leadership, teamwork and work engagement as independent variables. The results of the identification of the strength of the relationship between research variables, it can be concluded as follows: There is a significant positive relationship between Transformational Leadership (X1) and Teacher Creativity (Y) so that the strengthening of transformational leadership can increase teacher creativity. There is a significant positive relationship between Teamwork (X2) and Teacher Creativity (Y) so that strengthening teamwork can increase teacher creativity. There is a significant positive relationship between Work Engagement (X3) and teacher creativity (Y) so that strengthening work engagement can increase teacher creativity. There is a significant positive relationship between Transformational Leadership (X1) and Teamwork (X2) together with Teacher Creativity $(\mathrm{Y})$ so that strengthening transformational leadership and teamwork together can increase teacher creativity. There is a significant positive relationship between Transformational Leadership (X1) and Work Engagement (X3) together with Teacher Creativity (Y) so that the strengthening of transformational leadership and work engagement together can increase teacher creativity. There is a significant positive relationship between Teamwork (X2) and Work Engagement (X3) together with Teacher Creativity (Y) so that the strengthening of teamwork and work engagement together can increase teacher creativity. There is a significant positive relationship between Transformational Leadership (X1), Teamwork (X2) and Engagement Work (X3) together on Teacher Creativity (Y) so as to strengthen transformational leadership, teamwork dan keterlibatan kerja secara bersamasama dapat meningkatkan kreativitas guru.

\section{References}

Abdallah, A.B., Obeidat, B.Y, Aqqad, N.O, Al Janini, M. N. K.and Dahiyat, S.E. (2017). An Integrated Model of Job Involvement, 
Job Satisfaction and Organizational Commitment: A Structural Analysis in Jordan's Banking Sector. Communications and Network.

Angelo, K dan Brian K.W. (2008). Managemen A Practical Introduction, New York: McGraw-Hill.

Bass, B.M. \& Riggio, R.E. (2006). Transformational Leadership, London: Lawrence Erlbaum Associates, Publishers.

Budio, Sesra dan Fadlan, Amul Husni. (2020). Strategi Kepala Sekolah dalam Meningkatkan Kreativitas Guru, Jurnal Menata, Volume 3, No 1, Januari-Juni 2020, STAI YAPTIP, Pasaman Barat.

Britt, T.W., Dickinson, J.M., Shortridge, T.M.G. and McKibben, E. S. (2007). Self-Engagement at Work, in D. L. Nelson and C. L. Cooper (Eds.). Positive Organizational Behavior, London: Sage Publications.

Cahyandani, P.T. (2021). Pengaruh Kepemimpinan Transformasional dan Employee Engagement Terhadap Kinerja Karyawan PT. Taspen (Persero) Kantor Cabang Utama Surabaya, Jurnal Ilmu Manajemen Volume 9, Nomor 1. Universitas Negeri Surabaya.

Chen, C-C., \& Chiu, S-F. (2009). The Mediating Role of Job Involvement in the Relationship Between Job Characteristics and Organizational Citizenship Behavior. The Journal of Social Psychology. http://doi:10.3200/socp.149.4.474-494.

Champoux, J.E. (2010). Organizational Behavior: Integrating Individuals, Groups, and Organizations. Fourth Edition, New York \& London: the Taylor \& Francis e-Library.

Colquitt, J.A. Lepine, J.A. Wesson, M.J. (2015) Organizational Behavior: Improving Performance and Commitment in The Workplace. Fourth Edition, New York: McGraw-Hill.

Creswell, J.W. (2009). Research Design: Qualitative, Quantitative. And Mixed Methods Approaches, London: Sage Publications.

Darma, Dzul Qarnaen. (2021). Penguatan Teamwork, Kepemimpinan Visioner dan Efikasi Diri dalam Upaya Meningkatkan Kreativitas Guru (Studi Analisis Korelasional dan SITOREM pada Guru Tetap Yayasan Sekolah Menengah Kejuruan se Kota Bogor), (Disertasi) Sekolah Pascasarjana, Universitas Pakuan, Bogor.

Fathurrahman, A., Sumardi, Yusuf, A.E. dan Harijanto, S. (2019). Peningkatan Efektivtas Pembelajaran Melalui Peningkatan Kompetensi Pedagogik dan Teamwork, Jurnal Manajemen Pendidikan, Vol.7, No. 2, Juli 2019, P-ISSN 2302-0296, E-ISSN 2614-3313.

Ghani, A., Abdullah, K., Ling, Ying-Leh (2018), Principal Transformational Leadership and Teachers' Motivation, Asian Education Studies; Vol. 3, No. 1; February 2018, ISSN 24248487 E-ISSN 2424-9033, July Press, https://doi.org/10.20849/ aes.v3i1.316.

Ghifar, R., Yusuf, A.E., Sumardi, dan Wulandari, F. (2019). Peningkatan Kreativitas Guru Melalui Pengembangan Supervisi Kepala Sekolah dan Iklim Organisasi, Jurnal Manajemen Pendidikan Vol.7, No.2, Juli 2019 P-ISSN 2302-0296 E-ISSN 2614-3313.

Gibson, J.M. Ivancevich, J.H. Donnely, \& R. Konopaske. (20212). Organizations: Behavior, Structure \& Processes, Fourteenth Edition, New York: McGraw-Hill Companies.

Gong, Y., Huang, Jia-Chi; \& Farh, Jiing-Lih. (2009). Employee Learning Orientation, Transformational Leadership, and Employee Creativity: The Mediating Role of Employee Creative Self-Efficacy, Academy of Management Journal 2009, Vol. 52,
No. 4, 765-778, The Hong Kong University of Science and Technology.

Greenberg, J. dan Robert A.B. (2008). Behavior In Organization. Eigth Edition. Prentice Hall, New Jersey.

Hardhienata, S. (2017). The Development of Scientific Identification Theory to Conduct Operation Research in Education Management. IOP Conf. Series: Material Science and Engineering, Vol. 166. doi: 10.1088/1757-899X/166/1/2007,

Handayani, Ririn dan Heri, Helwen (2019), Pengaruh Kepemimpinan Terhadap Meningkatnya Orientasi Pembelajaran dan Kreativitas Guru SMA di Kota Pekanbaru, KAFA'AH JOURNAL, 9 (1), 2019, (12-25), Print ISSN 2356-0894 Online ISSN 2356-0630.

Y., Sayuti, A.J., Widarti, G.A.O dan Setiawan, H. (2020). Keterkaitan Antara Keterlibatan Karyawan, dan Kinerja Karyawan: Kreativitas Karyawan, Politeknik Negeri Sriwijaya, Palembang. Akuntabel 17 (2), 2020. http://journal.feb.unmul.ac.id/ index.php/AKUNTABEL ISSN: 0216-7743 - eISSN: 2528-11 35 241;

Judeh, Mahfuz (2011). An Examination of the Effect of Employee Involvement on Teamwork Effectiveness: An Empirical Study, International Journal of Business and Management, Vol. 6, No. 9; September 2011, ISSN 1833-3850E-ISSN 1833-8119, doi:10.5539/ijbm.v6n9p202, www.ccsenet.org/ijbm

Kinicki, Angelo and William, Brian K, dan Robbins dan Coulter (2014), Management: A Practical Introduction. A Promise: to Make Learning Management Easy, Efficient, and Affective. 5th Edition: McGraw-Hill Connect Management.

Kosasih, Achmad (2016) Pengaruh Kepemimpinan Transformasional, Budaya Organisasi dan Motivasi Kerja Pegawai Terhadap Kepuasan Kerja Pegawai serta Implikasinya pada Kinerja Pegawai PDAM di Provinsi Banten, Universitas Pansundan, Bandung.

Lakoy, Amanda Carolina (2015), Pengaruh Komunikasi, Kerjasama Kelompok, dan Kreativitas terhadap Kinerja Karyawan Pada Hotel Aryaduta Manado, Jurnal EMBA, Vol.3 No.3 Sept. 2015, ISSN 2303-11, Hal.981-991, Universitas Sam Ratulangi Manado.

Laurie J. Mullins. (2008). Management and Organisational Behaviour. Harlow, Essex, England: Pearson Education.

Leonardo S., Ferdinan dan Gatari, E. (2020). The Mediating Role of Work Engagement in The Relationship Between Meaningful Work and Turnover Intention of Millennials, Psikohumaniora: Jurnal Penelitian Psikologi, Vol 5, No 1 (2020), ISSN 25029363 (print); ISSN 2527-7456 (online), DOI: http://dx.doi. org/10.21580/pjpp.v5i1.4305.http://journal.walisongo.ac.id/ index.php/Psikohumaniora/2.

Lioa, C-S and Lee, C-W. (2009). An Empirical Studies of Employee Job Involvement and Personality Traits: The Case of Taiwan. International Journal of Economics and Management, Vol. 3, No. 1, 2009.

Luthans, Fred. (2006). Organizational Behavior: An Evidence-Based Approach, 12th Edition, The McGraw-Hill Companies, New York; 2006, ISBN: 978-0-07-353035-2, MHID: 0-07-353035-2.,

Ma, X., Jiang, W., Wang, L. \& Xiong, J. (2020). A Curvilinear Relationship Between Transformational Leadership And Employee Creativity, Management Decision, 04 Maret 2020, DOI; 10.1108/MD-07-2017-0653.

Marasabessy, Z.A. dan Santoso, B. (2016). Pengaruh Dukungan Rekan Kerja Pada Kreativitas Karyawan dengan Autonomi Kerja dan 
Efikasi-Diri Kreatif Sebagai Pemoderasi, Jurnal Siasat Bisnis, Vol 18 No. 1, Januari 2016, hal 32-34. ISSN : 0353 - 7665.

McShane, S.L. \& Glinow, M.A.V. (2010). Organizational Behavior: Emerging Knowledge and Practice for The Real World, 5th Ed., The McGraw-Hill Companies, New York, 2010, ISBN-13: 9780-07-338123-7.

Mehta, Sandhya, (2011). Job Involvemment Among Working Women, International Journal of Mulltidisciplinary Research. Vol 1, Issue 2, 2011.

Musinguzi, C., Namale, L., Rutebemberwa, E., Dahal, A., NahiryaNtege, Patricia \& Kekitiinwa, A. (2021). The Relationship Between Leadership Style and Health Worker Motivation, Job Satisfaction and Teamwork in Uganda, Journal of Healthcare Leadership, https://www.dovepress.com/ by 115.178 .195 .177 on 16-Jan-2021.

Ngalimun, Haris, dkk, (2013). Perkembangan dan Pengembangan Kreativitas, Yogyakarta: Aswaja Pressindo.

Northhouse, Peter G. (2013). Leadership: Theory dan Practice, California: Sage Publication.

Nofrida, Elvi. (2014). Hubungan Iklim Kerjasama dengan Semangat Kerja Pegawai pada Dinas Pendidikan Kota Solok, Volume 2, Juni 2014, Bahana Manajemen Pendidikan, Jurnal Administrasi Pendidikan, Universitas Negeri Padang.

Prasnavidya, Messiah. (2020). Peningkatan Komitmen Terhadap Organisasi Melalui Penguatan Kualitas Kehidupan Kerja, Teamwork, dan Organisasi Pembelajar (Studi Empirik menggunakan Pendekatan Korelasi dan Analisis SITOREM pada Guru Tetap Yayasan SMA Swasta di Kabupaten Bogor), (Disertasi) Sekolah Pascasarjana, Universitas Pakuan, Bogor.

Purba, Vitria Lilian. (2013). Teamwork: Studi Indigenous pada Karyawan Pns dan Swasta Bersuku Jawa, Journal of Social and Industrial Psychology, Vol 2, No. 2, 2013, Universitas Negeri Semarang.

R. Kreitner and A. Kinicki. (2010). Organizational Behavior. New York: McGraw-Hill.

Rahmawati, Femy Melia. (2020). Analisis Sequential Exploratory Komitmen Terhadap Organisasi Guru TK Swasta di Kabupaten Sukabumi, (Disertasi), Sekolah Pascasarjana, Universitas Pakuan, Bogor.

Ranjbar, M., Rafiei, S., Shafiei, M., \& Kargar, V. (2019). Transformational Leadership Style and Employee Creativity A Case Study in Yazd Medical University, The Health Care Manager Volume 38, Number 3. 2019 Wolters Kluwer Health, Inc. DOI: 10.1097/ HCM.0000000000000275

Rizwan, M., Khan, D.J. \& Saboor, F. (2011). Relationships of Job Involvement with employee Performance: Moderating Role of Attitude, European Journal of Business and Management, Vol. 3, No. 8, 2011, Malaysia.

Stephen, P.R. dan Timothy, A.J. (2013). Organizational Behavior, London: Pearson Education Ltd.

Stephen, P.R. dan Timothy, A.J. (2013), Organizational Behavior, Edition 15, New Jersey: Prentice Hall.

Salu, O.J.R., \& Hartijasi, Y. (2018). Analisis Pengaruh Work Engagement Sebagai Mediator Antara Job Resources dan Kepemimpinan Tranformasional Terhadap Organizational Commitment Dan Job Performance di Lembaga Pendidikan Indonesia Amerika, Jurnal Bisnis Manajemen dan Informatika (JBMI), Vol. 14, No. 3 Februari 2018, Universitas Indonesia.

Sari, Yusni. (2013). Peningkatan Kerjasama di Sekolah Dasar, Volume 1, Nomor 1, Oktober 2013,Bahana Manajemen Pen- didikan, Jurnal Administrasi Pendidikan, Universitas Negeri Padang.

Shaheen, A. and Farooqi, Y. A. (2014). Relationship among Employee Motivation, Employee Commitment, Job Involvement, Employee Engagement: A Case Study of University of Gujrat, Pakistan. International Journal of Multidisciplinary Sciences and Engineering, Vol. 5, No. 9, September 2014.

Smith, J.S. \& Correl, C. (2014). Teamwork and Work Team: Is There Any Difference. Journal of Quality Management, Vo. 2, No. 2, 2014.

Somani, A., \& Khrisnan, V.R. (2014). Impact of Charismatic Leadership and Job Involvement on Corporate Image Building. Journal of Management and Labour Studies, Vol. 29, No. 1, Feb.2004.

Sudrajat, A., Setiyaningsih, S., dan Sarimanah, E. (2020). Peningkatan Kreativitas Guru Melalui Pengembangan Servant Leadership dan Efikasi Diri Guru Tetap Yayasan, Jurnal Manajemen Pendidikan, Volume 08, No. 2, Juli 2020, e-ISSN:2614-3313;pISSN:2302-0296, Penerbit: Sekolah Pascasarjana, Universitas Pakuan, https://journal.unpak.ac.id/index.php/jmp.

Sugiarti, Retnowati, R. dan Suhardi, E. (2018), Hubungan Antara Kompetensi Profesional dan Motivasi Berprestasi dengan Kreativitas Kerja Guru, Jurnal Manajemen Pendidikan Vol.6, No.2, Juli 2018 P-ISSN 2302-0296 E-ISSN 2614-3313.

Suharyati, H., Abdullah, T. dan Rubini, B. (2016). Relationship Between Organizational Culture, Transformational Leadership, Working Motivation to Teacher's Innovativeness, International Journal of Managerial Studies and Research (IJMSR), Volume 4, Issue 3, March 2016, PP 29-34, ISSN 2349-0330 (Print) \& ISSN 2349-0349 (Online), www.arcjournals.org,

Sugiyono, (2019). Metodologi Penelitian Pendidikan, Cetakan Ketiga, Bandung: Alfabeta, 2019, ISBN 978-402-289-520-6.

Sugiyono, (2017). Metode Penelitian Kuantitatif, Cetakan Kedua, Bandung: Alfabeta, 2017, ISBN 978-602-289-373-8.

Sugiyono, (2019). Statistik untuk Penelitian, Cetakan Ketigapuluh, Bandung: Alfabeta, 2019, ISBN 978-979-843-310-8.

Sulistyo, Adhe Rachman \& Suhartini. (2019). The Role of Work Engagement in Moderating the Impact of Job Characteristics, Perceived Organizational Support, and Self-Efficacy on Job Satisfaction, IJBE (Integrated Journal of Business and Economics). e-ISSN:2549-3280/p-ISSN:2549-5933, Islamic University of Indonesia, 2019, DOI: 10.33019/ijbe.v3i1.112.

Sultika, Budi dan Hartijasti, Yanki. (2017). Faktor-Faktor yang Memengaruhi Kreativitas dan Orientasi Inovasi di Tempat Bekerja, Jurnal Riset Bisnis dan Manajemen Tirtayasa (JRBMT), Vol. 1 (2), Nopember 2017. ISSN (Online) 2599-0837, http://jurnal.untirta.ac.id/index.php/JRBM.

Syah, Darwyan. (2014. Kontribusi Kepemimpinan Transformasional Kepala Madrasah, Kinerja Mengajar Guru, dan Kultur Belajar Terhadap Peningkatan Prestasi Madrasah Aliyah Negeri Provinsi DKI Jakarta, Jurnal Pendidikan dan Kebudayaan, Volume. 20, Nomor 2, Juni 2014.

Tabassi, A.A., Ramli, M., Bakar, A.H.A, and Pakir, A.H.D. (2014), Transformational Leadership and Teamwork Improvement: The Case of Construction Firms, Journal of Management Development Vol. 33 No. 10, 2014, Emerald Group Publishing Limited Universiti sains Malaysia. DOI 10.1108/JMD-01-2012-0003

Umyati, S., dan Suhardi, E. (2019). Hubungan Antara Budaya Sekolah dan Kompetensi Pedagogik dengan Kreativitas Guru, Jurnal 
Manajemen Pendidikan Vol.7, No.2, Juli 2019 P-ISSN 23020296 E-ISSN 2614-3313.

Wahyuni, M. Entang, dan Herfina. (2019). Peningkatan Produktivitas Kerja Guru Melalui Pengembangan Supervisi Kepala Sekolah dan Kreativitas Kerja, Jurnal Manajemen Pendidikan Vol. 7, No.1, Januari 2019 P-ISSN 2302-0296 E-ISSN 2614-3313.

Wahyuni, Akhtim (2013). Pengembangan Kreativitas Guru Sebagai Modal Penerapan Kurikulum 2013, Article · 15 December 2016, Universitas Muhammadiyah Sidoarjo, https://www.researchgate.net/publication/311649814.

Wajong, B.E.R., Dadang, I., Wylen, dan Bernarto, I. (2020). Persepsi Karyawan pada CSR, Keterlibatan Karyawan, dan Kepemimpinan Etis Pengaruhnya terhadap Kreatifitas Karyawan, Universitas Pelita Harapan, Tangerang, Indonesia, Jurnal Administrasi Bisnis (JAB), Vol. 10. No. 2, 2020, (p-ISSN 23389605; e-2655-206X).

Wang, Yuan \& Hu, Ti (2017). Transformational Leadership Behavior and Turnover Intention in China Physical Education, EURASIA Journal of Mathematics Science and Technology
Education ISSN: 1305-8223 (online) 1305-8215 (print) 2017 13(9):6357-6368, DOI: 10.12973/eurasia.2017.01070a, September 2017, pp 6358-6359.

Wijayanti, I.A.D., dan Supartha, W.G. (2019). Pengaruh Kepemimpinan Transformasional Terhadap Kreativitas Karyawan Dimediasi Efikasi Diri Kreatif pada PT. Aura Bali Craft, Universitas Udayana, Bali, Indonesia. E-Jurnal Manajemen Unud, Vol. 8, No. 3, 2019: . p3. ISBN: 1230 - 1254 ISSN: 2302-8912 DOI: https://doi.org/10.24843/EJMUNUD.2019.v8.i3.

Wingerden, J.V., Stoep, O.V.D., and Poell, R. (2018). Meaningful Work and Work Engagement: The Mediating Role of Perceived Opportunities to Craft and Job Crafting Behavior, International Journal of Human Resource Studies ISSN 2162-3058 2018, Vol. 8, No. 2, p.3, https://doi.org/10.5296/ijhrs.v8i2.12635, http://www.ijhrs.macrothink.org/

Yubo Hou, Ge Gao, Fei Wang, Tingrui Ri, and Zhilan Yu (2011).. Organizational Commitment and Creativity. Annals of Economics and Finance, Vol. 12 (2), 2011.

Yuki, Gary. (2010). Leadership in Organizations, Sevent Edition, Pearson Education International, New Jersey. 